\title{
PENERAPAN MODEL PICTURE AND PICTURE BERBASIS PENDEKATAN SAINTIFIK UNTUK MENINGKATKAN HASIL PENGETAHUAN IPA
}

\author{
Putu Ari Susanti ${ }^{1}$, Ni Nyoman Kusmariyani ${ }^{2}$ \\ ${ }^{1}$ Universitas Pendidikan Ganesha \\ 2Universitas Pendidikan Ganesha
}

\begin{abstract}
Abstrak
Penelitian ini bertujuan untuk meningkatakan penguasaan kompetensi pengetahuan IPA melalui penerapanmodel Picture And Picture berbasis Pendekatan Saintifik. Jenis penelitian ini adalah Penelitian Tindakan Kelas (PTK). Data dikumpulkan dengan metode tes, kemudian data dianalisis dengan teknik analisis satatistik deskriptif dan analisis deskriptif kuantitatif. Hasil penelitian menunjukan ketuntasan klasikal pada siklus I sebesar 55\%, selanjutnya mengalami peningkatan pada siklus II menjadi $88 \%$. Peningkatan yang terjadi dari siklus I ke siklus II sebesar 38\%. Sehingga dapat disimpulkan bahwa penerapan model Picture And Picture berbasis Pendekatan Saintifik dapat meningkatkan penguasaan kompetensi pengetahuan IPA siswa kelas IV SD N 6 Sumerta
\end{abstract}

\section{Keywords:}

penerapan picture and picture, saintifik, ompetensi IPA

\section{Pendahuluan}

Pendidikan memegang peranan yang sangat penting dalam dinamika kehidupan suatu bangsa. Pendidikan dapat dikatakan sebagai agen pembangunan dan agen perubahan. Tanpa pendidikan, tidak akan ada pembangunan yang berarti tidak akan ada perubahan. "Majunya pendidikan akan menunjukan kemajuan suatu bangsa, begitu pula mundurnya pendidikan akan menjerumuskan bangsa kepada kebodohan dan kemiskinan" (Suryadi, 2009). Pendidikan yang ideal tidak hanya berorientasi pada masa lalu dan masa kini, tetapi sudah seharusnya merupakan proses yang mengantisipasi dan membicarakan masa depan. Pendidikan merupakan pondasi utama dalam mengelola, mencetak, dan meningkatkan SDM yang berkualitas tinggi yang diharapkan mampu untuk menjawab tantangan di masa yang akan datang. Menurut Tillar (2000), "kualitas pendidikan yang baik dapat menciptakan kehidupan yang cerdas, harmonis, dan mampu mengelola potensi yang ada, serta mampu bersaing secara kompetitif". Oleh karena itu, peningkatan kualitas pendidikan sangat penting dilaksanakan apabila Indonesia ingin memiliki SDM yang bermutu tinggi.

Buchori (dalam Trianto, 2008) mengatakan bahwa "pendidikan yang baik adalah pendidikan yang tidak hanya mempersiapkan para siswanya untuk sesuatu profesi atau jabatan, tetapi untuk menyelesaikan masalah-masalah yang dihadapinya dalam kehidupan sehari-hari". Salah satu bidang ilmu yang dapat membantu siswa dalam menyelesaikan permasalahan yang dihadapinya dalam kehidupan sehari-hari adalah ilmu pengetahuan alam (IPA). Pengembangan IPTEK juga berkaitan erat dengan penguasaan IPA. Teknologi yang dinikmati sekarang sebagian besar tercipta melalui penerapan konsep dan prinsip IPA yang diwujudkan secara teknis dalam berbagai bentuk alat dan produk teknologi.

IPA mengandung tiga dimensi utama, yaitu dimensi produk, proses, dan sikap ilmiah. Dimensi produk IPA berupa fakta, konsep, prinsip, hukum, dan teori IPA (Astiti, dkk., 2017). Dimensi proses, maksudnya adalah bagaimana proses mendapatkan IPA. IPA diperoleh melalui penelitian dengan menggunakan langkah-langkah tertentu yang disebut metode ilmiah. Dimensi proses ini sangat penting dalam menunjang proses perkembangan peserta didik, anak tidak hanya memperoleh pengetahuan tetapi juga memperoleh kemampuan untuk menggali sendiri pengetahuan itu dari alam bebas. Melalui dimensi proses IPA akan dapat mengembangkan sikap ilmiah. Salah satu indikator untuk melihat tingkat keberhasilan pengembangan kemampuan peserta didik dalam bidang IPA adalah hasil belajar IPA siswa. Hasil belajar IPA inilah yang nantinya akan menunjukan tingkat penguasaan IPA dari siswa. Oleh karena pentingnya IPA, maka peningkatan hasil belajar IPA secara berkesinambungan sudah menjadi pekerjaan 
rumah bagi pemerintah dan pihak-pihak yang terlibat dalam bidang pendidikan.

IPA berkaitan dengan cara mencari tahu tentang alam secara sistematis, sehingga IPA bukan hanya penguasaan kumpulan pengetahuan yang berupa fakta-fakta, konsep-konsep, atau prinsip-prinsip saja akan tetapi juga merupakan suatu proses penemuan. Pendidikan IPA diharapkan dapat menjadi wahana bagi peserta didik untuk mempelajari diri sendiri alam sekitar, serta prospek pengembangan lebih lanjut dalam penerapannya di dalam kehidupan sehari-hari serta menggunakan pendekatan saintifik. Pendekatan saintifik dirancang agar siswa aktif dalam mengkonstruksikan konsep dan prinsip melalui keilmuan. Belajar dengan pendekatan saintifik dapat menghantarkan siswa dalam menemukan dan mengaplikasikan konsep - konsep yang ditemukan dalam proses pembelajaran ke dunia nyata, sehingga dengan menerapkan pendekatan saintifik pengalaman belajar yang diperoleh siswa tidak hafalan sebaliknya lebih bersifat faktual.

Pelajaran IPA yang menerapkan pendekatan saintifik merupakan pembelajaran yang berhubungan dengan gejala alam yang diperoleh dengan cara observasi dan eksperimen serta mengutamakan rasa ingintahu dan berpikir kritis sehingga siswa memperoleh pemahaman, pembelajaran dan pengalaman yang terkumpul menjadi satu dan dapat diaplikasikan ke dalam masalah tertentu dalam kehidupan sehari-hari yang di alami siswa itu sendiri. Hal ini diperkuat oleh pendapat dari Aly (2009) menyatakan bahwa IPA merupakan suatu ilmu teoretis, teorinya didasarkan atas pengamatan, percobaanpercobaan terhadap gejala-gejala alam. Winaputra (dalam Samatowa 2010) menyatakan bahwa IPA merupakan ilmu yang berhubungan dengan gejala alam dan kebendaan yang sistematis yang tersusun teratur, berlaku umum yang berupa kumpulan dari hasil observasi dan eksperimen/sistematis. Pelajaran IPA merupakan salah satu materi ajar yang memiliki kompetensi yang masih rendah. Masih rendahnya penguasaan kompetensi pengetahuan IPA siswa karena ada kendala dalam pelaksanaan pembelajaran. Kendala ini menimbulkan kesenjangan yang cukup besar antara yang diharapkan dari muatan materi IPA yaitu memupuk rasa ingin tahu secara alamiah.

Berdasarkan hasil observasi pada pembelajaran IPA di Kelas IV SD N 6 Sumerta memiliki kendala yang terdapat dalam pelaksanaan pembelajaran yaitu sebagai berikut. (1) Siswa kurang semangat dalam merespon pembelajaran yang berlangsung. Sebagian siswa masih tidak mau mendengarkan guru dan tidak menghiraukan guru saat memaparkan meteri. (2) Siswa tidak fokus dalam mengikuti pembelajaran. Masih banyak siswa yang lain - lain dan bercanda saat guru menyampaikan materi sehingga berdampak pada suasana kelas ramai dikarenakan ribut. Suasana yang ribut menyebabkan siswa yang memiliki keinginan yang dalam belajar menjadi terganggu. Akibatnya siswa bosan dan kurang antusias dalam mengikuti pelajaran. Indikatornya antara lain kurangnya semangat siswa mengikuti pelajaran, rendahnya pemusatan perhatian siswa serta rendahnya respon umpan balik dari siswa terhadap pertanyaan guru.

Akibatnya penguasaan dan pemahaman mata pelajaran IPA di kelas IV SD N 6 Sumerta sampai saat ini belum mencapai hasil sesuai dengan yang diharapkan. Ulangan harian dan ulangan umum siswa kelas IV N 6 Sumerta menunjukkan masih banyak siswa yang nilainya baru sebatas nilai minimal lulus (KKM) yaitu 70. Siswa mengatakan bahwa materi pelajaran yang membuat bingung adalah IPA, karena muatan materi IPA sulit dipahami. Munculnya permasalahan yang dihadapi ini karena guru menerapkan model pembelajaran yang kurang sesuai dengan karakteristik siswa. Dalam pembelajaran dapat diatasi dengan pemberian variasi yang dapat diberikan dalam proses pembelajaran. Variasi yang dimaksud yaitu dengan diterapkannya pendekatan saintifik yang dikolaborasikan dengan salah satu model pembelajaran yang dapat mendorong siswa menjadi aktif dan lebih giat dalam menemukan pengetahuannya dan sesuai dengan karakteristik siswa. Pendekatan saintifik merupakan pendekatan yang mengutamakan kreativitas dan temuan-temuan siswa di dalam kegiatan pembelajaran. Salah satu model yang diterapkan yaitu model picture and picture.

Picture and Picture adalah suatu metode belajar yang menggunakan gambar yangdipasangkan atau diurutkan menjadi urutan logis (Hamdani, 2010). Kelebihan dan Kelemahan Model Pembelajaran picture and picture menurut (Hamdani, 2010). Kelebihan: 1) Guru lebih mengetahui kemampuan tiap-tiap siswa, 2) Melatih siswa untuk berpikir logis dan sistematis. Kelemahan: 1) Memakan banyak waktu, 2) Banyak siswa yang pasif. Sedangkan menurut Istarani (Aprudin, 2012) kelebihan dan kekurangan picture and picture yaitu: Kelebihan Model Pembelajaran picture and picture 1) Materi yang diajarkan lebih terarah karena pada awal pembelajaran guru menjelaskan kompetensi yang harus dicapai dan materi secara singkat terlebih dahulu. 2) Siswa lebih cepat menangkap materi ajar karena guru menunjukkan gambar-gambar mengenai materi yang dipelajari. 3) Dapat meningkat daya nalar atau daya pikir siswa karena siswa disuruh guru untuk menganalisa gambar yang ada. 4) Dapat meningkatkan tanggung jawab siswa, sebab guru menanyakan alasan siswa mengurutkan gambar. 5) Pembelajaran lebih berkesan, sebab siswa dapat mengamati langsung gambar yang telah dipersiapkan oleh guru

Kelemahan Model Pembelajaran picture and picture 1) Sulit menemukan gambar-gambar yang bagus dan berkulitas serta sesuai dengan materi pelajaran. 2) Sulit menemukan gambar-gambar yang 
sesuai dengan daya nalar atau kompetensi siswa yang dimiliki. 3) Baik guru ataupun siswa kurang terbiasa dalam menggunakan gambar sebagai bahan utama dalam membahas suatu materi pelajaran. 4) Tidak tersedianya dana khusus untuk menemukan atau mengadakan gambar- gambar yang diinginkan.

Langkah-langkah Pembelajaran dengan picture and picture (Hamdani, 2010) antara lain: 1) Guru menyampaikan kompetensi yang ingin dicapai. 2) Guru menyajikan materi sebagai pengantar. 3) Guru menunjukkan gambar-gambar yang berkaitan dengan materi. 4) Guru menunjuk atau memanggil siswa secara bergantian untuk memasang atau mengurutkan gambar-gambar menjadi urutan yang logis. 5) Guru menanyakan alasan atau dasar pemikiran urutan gambar tersebut. 6)Dari alasan atau urutan gambar tersebut, guru menanamkan konsep atau materi sesuai dengan kompetensi yang ingin dicapai. 7) Guru bersama siswa menyimpulkan materi yang telah diajarkan.

Model picture and picture merupakan model pembelajaran yang kooperatif atau mengutamakan adanya kelompok - kelompok dengan menggunakan media gambar yang dipasangkan atau diurutkan menjadi urutan yang logis (Kurniasih, 2015). Dalam pelaksanaa model picture and picture dapat membantu siswa menyamakan persepsi tentang gambar yang dihadirkan, sehingga setiap anggota kelompok mempunyai tujuan yang sama. Kelebihan dari model picture and picture melatih siswa untuk berpikir logis dan sistematis. Membantu siswa belajar berpikir berdasarkan sudut pandang suatu subjek bahasan dengan memberikan kebebasan siswa beragumen terhadap gambar yang diperlihatkan. Selain itu, dapat memunculkan motivasi belajar siswa kearah yang lebih baik. Langkah-langkah pelaksanaan pembelajaran dengan menggunakan model picture and picture dipaparkan oleh Kurniasih (2015) menyatakan bahwa teknis pelaksanaan model picture and picture yaitu: 1) Guru menyampaikan tujuan pembelajaran yang ingin di capai; 2) Guru menyampaikan pengantar pembelajaran; 3) Guru memperlihatkan gambar - gambar yang telah disiapkan; 4) Langkah selanjutnya siswa dipanggil secara bergantian untuk mengurutkan gambar - gambar menjadi urutan logis; 5) Guru menanyakan alasan logis urutan gambar; 6) Setelah gambar menjadi urut, guru harus bisa menanamkan konsep atau materi sesuai dengan kompetensi yang ingin dicapai.

Model pembelajaran picture and picture merupakan model pembelajaran yang menuntut siswa harus dapat bertanggung jawab atas segala sesuatu yang dikerjakan dalam kelompoknya. Disamping itu, siswa juga harus menyamakan persepsi tentang gambar yang dihadirkan, sehingga setiap kelompok mempunyai tujuan yang sama. Hal ini yang harus diperhatikan dalam model pembelajaran ini bahwa siswa harus bisa membagi tugas dan tanggung jawab dalam kelompoknya, serta dapat memberikan evaluasi pada setiap anggota kelompok dengan menunjuk juru bicara atau pemimpin mereka, dan hal ini bisa dilakukan secara bergantian. Hal ini sangatlah memberikan manfaat pada siswa karena dengan mengguakan model picture and picture siswa akan belajar secara berkelompok dalam menemukan pengetahuannya, siswa juga dilatih untuk percaya diri dalam menjawab pertanyaan yang guru berikan dan yang terpenting penguasaan kompetensi siswa dapat meningkat. Manfaat dalam model picture and picture didukung oleh pendapat dari Kurniasaih (2015) yang menyatakan kelebihan-kelebihan yang dimilikinya oleh model picture and picture yaitu,1) Guru bisa dengan mudah mengetahui kemampuan masing - masing siswa; 2) Model picture and picture ini melatih siswa untuk berpikir logis dan sistematis; 3) Membantu siswa belajar berpikir berdasarkan sudut pandang suatu subjek bahasan dengan memberikan kebebasan siswa berargumen terhadap gambar yang diperlihatkan; 4) Dapat memunculkan motivasi belajar siswa kearah yang lebih baik; 5) Siswa dilibatkan dalam perencanaan dan pengelolaan kelas.

Dengan demikian penerapan model picture and picture akan membuat siswa aktif dalam menemukan pengetahuannya dan berusaha untuk dapat menyampaikan ataupun menjawab pertanyaan yang guru berikan. Pelaksanaan pembelajaran memiliki tujuan untuk mempersiapkan manusia Indonesia agar memiliki kemampuan hidup sebagai pribadi dan warga negara yang beriman, produktif, kreatif, inovatif, dan aktif serta mampu berkontribusi pada kehidupan bermasyarakat, berbangsa, bernegara, dan peradaban dunia (Lampiran I Permendikbud 57). Dengan kata lain, hasil yang diperoleh siswa berupa sikap (ketuhanan dan sosial), pengetahuan dan keterampilan yang nantinya dapat bermanfaat bagi dirinya dan lingkungannya. Pembelajaran IPA seharusnya menggunakan pendekatan saintifik atau pendekatan berbasis proses keilmuan (Permendikbud No 103). Pendekatan saintifik merupakan pendekatan yang mengutamakan kreativitas dan temuan-temuan siswa di dalam kegiatan pembelajaran (Kosasih, 2015).

Pembelajaran dengan pendekatan saintifik adalah proses pembelajaran yang dirancang agar siswa secara aktif mengontruksikan konsep, hukum atau prinsip melalui pengalaman belajar seperti mengamati (untuk mengidentifikasi atau menemukan masalah), merumuskan masalah, mengajukan atau merumuskan hipotesis, mengumpulkan data dengan berbagai teknik, menganalisis data, menarik kesimpulan dan mengomunikasikan konsep, hukum atau prinsip yang ditemukan" (Daryanto, 2014; Widiana, 2015) 
Pendekatan saintifik memiliki ciri khas yaitu, (a) berpusat pada siswa, (b) melibatkan keterampilan proses sain dalam mengkontruksi konsep, hukum atau prinsip, (c) melibatkan prosesproses kognitif yang potensial dalam merangsang perkembangan intelektual, khususnya keterampilan berpikir tingkat tinggi siswa, (d) dapat mengembangkan karakteristik siswa (Daryanto, 2014).

Sehingga penerapan pendekatan saintifik akan membuat siswa aktif dan kreatif dalam menemukan pengetahuannya sendiri, sedangkan model picture and picture yang dapat membantu siswa dalam memahami materi dengan cepat, mengembangkan kemampuan berbicara. Sehingga bila pendekatan saintifik dan model picture and picture dipadukan maka siswa menjadi aktif dan kreatif dalam menemukan pengetahuannya yang guru berikan dengan gambar. Hal ini dapat memberikan dampak pada peningkatan penguasaan kompetensi pengetahuan pada siswa, sehingga saat model picture and picture berbasis pendekatan saintifik diterapkan pada dalam muatan materi IPA dapat memberikan kesempatan pada siswa untuk menghubungkan materi yang ada dalam buku, dengan penerapannya dalam kehidupan sehari-hari dan pertanyaan yang telah guru siapkan. Jadi peningkatan pengalaman belajar atau penguasaan kompetensi pengetahuan IPA meningkat. Peningkatan kompetensi pengetahuan IPA siswa akan sejalan dengan hasil belajar pengetahuan IPA siswa. Sehingga dengan Penerapan Model Picture And Picture Berbasis Pendekatan Saintifik Untuk Meningkatkan Hasil Pengetahuan IPA ini diharapkan akan mampu mengatasi permasalahan dalam pembelajaran IPA yang terjadi di SD No. 6 Sumerta.

\section{Metode}

Penelitian ini merupakan penelitian tindakan kelas secara kolaboratif yang dilaksanakan di SD N 6 Sumerta dengan subjek siswa kelas IV karena bertujuan untuk memperbaiki kualitas pembelajaran yang bermuara pada peningkatan penguasaan kompetensi pengetahuan IPA siswa. Penelitian tindakan kelas ini dirancang dengan empat tahapan dalam satu siklus. Keempat tahapan dalam penelitian ini yaitu perencanaan, pelaksanaan, pengamatan, dan refleksi. Alur penelitian tindakan kelas dapat disajikan seperti pada gambar 1.

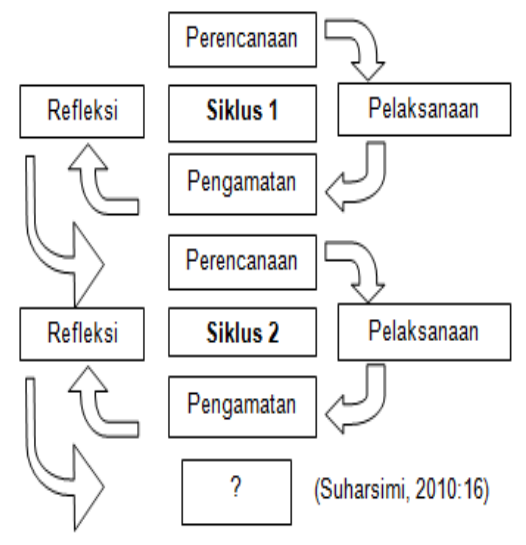

Gambar 1. Gambar Siklus PTK

Pelaksanaan setiap siklus terdiri dari empat kali pertemuan. Keempat petemuan tersebut dibagi menjadi 3 kali pertemuan untuk pelaksanaan pembelajaran menggunakan model Picture and Picture berbasis pendekatan saintifik dan 1 kali pertemuan pada akhir siklus untuk diadakannya tes evalusi. Pelaksanaan tes evaluasi akhir siklus didapatkan sebagai data penguasaan kompetensi pengetahuan IPA.

Siklus I meliputi empat tahapan, yakni perencanaan, pelaksanaan, pengamatan, dan refleksi. 1) Tahap Perencanaan. Pada kegiatan ini dilakukan penyusunan Rencana Pelaksanaan Pembelajaran (RPP), menyiapkan alat dan bahan/media pembelajaran, dan membuat instrumen penelitian. 2) Tahap Pelaksanaan. Pada tahap ini dilaksanakan pembelajaran sesuai dengan RPP yang telah disusun. 3) Tahap Pengamata. Kegiatan Pengaatan dilaksanakan selama kegiatan pembelajaran berlangsung. Seluruh kemajuan dan kendala yang terjadi selama pelaksanaan dicatat untuk dapat ditindaklanjuti. 4) Tahap Refleksi. Kegiatan yang dilakukan adalah menemukan solusi dari kendala yang ditemukan dalam pelaksanaan, sehingga solusi yang dibuat memperbaiki proses pembelajaran pada tindakan berikutnya.

Pelaksanaan siklus II mengacu pada hasil refleksi siklus I, yaitu untuk memperbaiki proses pembelajaran menggunkan model Picture and Picture berbasis pendekatan saintifik pada siklus I. Pelaksanaan siklus II pada asarnya sama dengan siklus I. Hanya saja, pada siklus II tindakan yang dilaksanakan adalah penyempurnaan dari siklus I. Sehingga tindakan pada siklus II mengalami perbaikan dalam proses pembelajarannya maupun. Dengan kata lain telah mampu mencapai tujuan yang 
direncanakan dan dilaksanakan pada penelitian ini. Pada akhir siklus II dilakukan suatu refleksi yang merupakan kegiatan akhir merumuskan hasil dari semua kegiatan.

Penelitian ini dilaksanakan pada tahun ajaran 2015/2016, di SD N 6 Sumerta. Subjek penelitian ini adalah siswa kelas IV SD N 6 Sumerta tahun ajaran 2016/2017 yang berjumlah 25 orang siswa. Sementara objek penelitian ini meliputi peguasaan kompetensi pengetahuan IPA dengan diterapkannya model picture and picture berbasis pendekatan saintifik.

Pengumpulan data dalam penelitian ini menggunakan metode tes, dengan instrumen berupa tes pilihan ganda biasa. Banyak soal yang diberikan pada setiap pelaksanaan evaluasi akhir siklus adalah sebanyak 15 soal yang berkaitan dengan muatan materi IPA. Soal-soal yang diberikan pada saat evaluasi akhir siklus terlebih dahulu dilakukan validitas isi agar ketepatan tes tersebut sesuai dengan perencanaan yang telah dibuat dalam kisi-kisi. Pengujian validitas isi dilakukan oleh guru kelas IV SD N 6 Sumerta .

Metode analisis data yang digunakan setelah data diperoleh dan terkumpul yaitu dengan analisis statistik deskriptif dan analisis deskriptif kuantitatif. Metode Analisis statistik deskriptif adalah cara pengelolaan data dengan yang dilakukan dengan jalan menerapkan rumus-rumus statistik deskriptif sehingga memperoleh kesimpulan umum (Agung, 2014; Purwanto, 2008). Sementara analisis deskriptif kuantitatif adalah suatu cara pengelolaan data yang dilakukan dengan jalan menyusun secara sistematis dalam bentuk angka-angka dan persentase, mengenal suatu objek yang diteliti sehingga memperoleh kesimpulan umum (Agung, 2012).

Secara keseluruhan penelitian dikatakan berhasil jika ketuntasan klasikal anak mencapai KKM minimal 80 dalam ketuntasan belajar pengetahuan IPA. Apabila indikator keberhasilan pada pencapaian penguasaan materi sudah tercapai, maka penelitian dihentikan dan akan dilanjutkan simpulan dan pembahasan bahwa siklus tersebut telah tercapai.

\section{Hasil dan pembahasan}

Penelitian tindakan kelas ini dilaksanakan di kelas IV SD N 6 Sumerta Tahun Ajaran 2016/2017. Penelitian ini yang terdiri dua siklus, siklus I dan siklus II masing-masing dilakukan dalam empat kali pertemuan. Data yang dikumpulkan pada penelitian ini adalah data penguasaan kompetensi pengetahuan IPA siswa dengan diterapkannya model pembelajaran picture and picture berbasis pendekan saintifik. Adapun hasil yang tercatat dalam observasi awal dengan menggunakan nilai ualngan umum semester I adalah siswa yang mencapi KKM hanya 11 orang dari 25 orang siswa. Dari 11 orang siswa yang mencapai KKM diperoleh persentase ketuntasan klasikal mencapai 44\%.

Setelah dilaksanakan siklus I dengan diterapkannya model picture and picture berbasis pendekatan saintifik dan dilaksanakan analisis data, tampak bahwa ketuntasan klasikal mencapai 55\% yang dari 25 orang siswa hanya 13 orang siswa mencapai KKM 70. Hasil yang diperoleh tersebut masih belum sesuai dengan indikator keberhasilan yang ditentukan. Hal ini dikarenakan beberapa kendala yang yaitu, siswa masih belum terbiasa belajar dan bekerja dalam kelompok, siswa masih enggan untuk mengajukan pertanyaan.

Dikarenakan belum tercapainya indikator keberhasilan maka dilanjutkan dengan pelaksanakan siklus II. Pelaksanaan penelitian pada siklus II dengan mempertimbangkan solusi untuk mengatasi kendala yang terdapat pada siklus I. Setelah dilaksanakan perbaikan pada siklus II, maka diperoleh ketuntasan klasikal mencapai $88 \%$ yang menunjukkan dari 25 orang siswa terdapat 22 siswa yang sudah mencapai KKM 70. Peningkatan penguasaan kompetensi pengetahuan IPA siswa terjadi karena kendala yang dihadapi pada siklus II tidak sebanyak di siklus I, bahkan pada akhir pelaksanaan siklus II sudah tidak ada lagi kendala-kendala seperti pada siklus I dan indikator keberhasilan yang telah ditetapkan sudah tercpai. Peningkatan yang terjadi pada ketuntasan klasikal disebabkan karena siswa sudah terbiasa dengan penerapan model picture and picture. Dengan demikian, siswa menjadi semangat untuk belajar serta lebih percaya diri untuk menjawab pertanyaan yang guru lontarkan bersamaan dengan tongkat yang guru bawa. Sehingga dapat diambil kesimpulan penerapan model picture and picture dapat meningkatkan penguasaan kompetensi pengetahuan IPA siswa kelas IV SD N 6 Sumerta dan penelitian sudah dapat dihentikan. Penerapan pendekatan saintifik dapat merubah proses pembelajaran IPA yang awalnya kurang diminati siswa menjadi menantang karena siswa melakukan lima pengalaman belajar pokok yaitu: a. Mengamati; b. Menanya; c. Mengumpulkan informasi; d. Mengasosiasi; e. Mengkomunikasikan.

Adapun rinkasan hasil penelitian terhadap penguasaan kompetensi pengetahuan IPA siswa kelas IV SD N 6 Sumerta disajikan pada Tabel 1. 
Tabel 1. Rinkasan Hasil Penelitian Penguasaan Kompetensi Pengetahuan IPA Siswa Kelas IV SD N 6 Sumerta

\begin{tabular}{ccc}
\hline & Sumerta & Siklus II \\
\hline Tahapan & Siklus I & 84,2 \\
Mean & 75,8 & $88 \%$ \\
\hline
\end{tabular}

Data yang ditampilkan pada Tabel 1 menunjukkan telah terjadi peningkatan penguasaan kompetensi pengetahuan IPA. Hal tersebut ditunjukan oleh meningkatnya mean dan ketuntasan klasikal. Berdasarkan data yang diperoleh pada siklus II, kriteria yang ditetapkan dalam penelitian ini sudah terpenuhi. Hal ini dapat dilihat pada tercapainya kriteria ketuntasan klasikal sudah mencapai persentase yang diharapkan yakni minimal 80\%, hal ini terwujud pada siklus II sudah mencapai 88\%. Oleh karena itu penelitian ini dapat dikatakan berhasil atau penelitian ini dapat dihentikan karena sudah mencapai kriteria yang diharapkan.

Pelaksanaan pembelajaran pada masing-masing siklus telah berlangsung dengan baik. Hasil penelitian yang diperoleh melalui penerapan model picture and picture berbasis pendekatan saintifik menunjukkan bahwa terjadi peningkatan pada penguasaan kompetensi pengetahuan IPA tema Peduli Terhadap Makhluk Hidup IV SD N 6 Sumerta.

Peningkatan ini tidak terlepas dari penerapan model picture and picture yang dikombinasikan dengan pendekatan saintifik. Model picture and picture merupakan model pembelajaran tipe kooperatif. Model picture and picture merupakan model pempebelajaran tipe kooperatif. Model pembelajaran kooperatif akan melatih siswa untuk dapat bekerjasama dalam menyelesaikan suatu masalah. Sehingga penggunaan model picture and picture dapat dikolaborasikan dengan pendekatan saintifik karena karakteristik yang dimiliki oleh model picture and picture yang interaktif, menantang siswa untuk dengan cepat menguasai materi pembelajaran, memotivasis siswa untuk berpartisipasi aktif dalam memberikan masukan berdiskusi dan menjawab soal.

Hasil penelitian yang diperoleh sejalan dengan hasil penelitian yang telah dilakukan sebelumnya. Bagus Gita Sawitra (2015) menunjukan Analisis data menggunakan uji-t sampel independen dengan rumus polled varians, menunjukkan thitung $=5,41<$ ttabel $=2,000$. Dilihat dari rata-rata skor juga menunjukkan perbedaan yang besar. Rata-rata skor yang diperoleh dari kelompok siswa yang dibelajarkan menggunakan model pembelajaran picture and picture berbantuan media PowerPoint adalah 83,021 lebih besar daripada rata-rata skor kelompok siswa yang dibelajarkan menggunakan model pembelajaran konvensional sebesar 73,25. Perbedaan keterampilan menulis yang signifikan antara kelompok siswa yang belajar menggunakanmodel pembelajaran picture and picture berbantuan media PowerPoint dengan kelompok siswa yang dibelajarkan menggunakan model pembelajaran konvensional

Sumber referensi yang kedua didapatkan dari jurnal penelitian Gede Risa Pebriana yang memperoleh hasil yang sejalan dengan penelitian ini. Pada siklus I, persentase rata-rata aktivitas belajar siswa pertemuan I dan pertemuan II adalah $72,22 \%$ berada pada kategori cukup aktif. Persentase ratarata hasil belajar IPA yang diperoleh siswa pada siklus I sebesar 76,44\% berada pada kategori sedang. Pada siklus II, aktivitas dan hasil belajar siswa mengalamai peningkatan. Persentase rata-rata aktivitas belajar siswa pertemuan I dan pertemuan II adalah $86,11 \%$ berada pada kategori aktif. Persentase ratarata hasil belajar siswa pada siklus II sebesar $87,11 \%$ berada pada kategori tinggi. Hasil penelitian siklus I dan II menunjukkan bahwa terjadi peningkatan persentase aktivitas dan hasil belajar IPA pada siswa kelas V semester ganjil SD N 1 Tegallinggah, Kecamatan Sukasada, Kabupaten Buleleng tahun pelajaran $2016 / 2017$.

\section{Simpulan dan Saran}

Berdasarkan hasil penelitian tindakan kelas yang dilakukan dan pembahasan serta hasil analisis data yang telah diuraikan sebelumnyan yaitu pada siklus I ketuntasan klasikal mencapai 55\% dengan mean mencapai 75,8. Penguasaan kompetensi pegetahuan IPA siswa pada siklus I masih rendah. Sedangkan pada siklus II ketuntasan klasikal naik mencapai 88\% dengan mean84,2 yang artinya penguasaan kompetensi pengetahuan IPA siswa tinggi.Peningkatan ketuntasan klasikal dari siklus I ke siklus II sebesar 38\%.

Jadi dapat disimpulkan bahwa penerapan model picture and picture berbasis pedekatan saintifik dapat meningkatkan penguasaan kompetensi pengetahuan IPA siswa kelas IV SD N 6 Sumerta Tahun ajaran 2016/2017.Berdasarkan simpulan dalam penelitian ini maka dapat diajukan saran kepada berbagai pihak sebagaiberikut. 1) Kepala Sekolah, agar dapat merekomendasikan kepada guru untuk mempertimbangkan serta mengembangkan penerapan model picture and picture berbasis pendekatan 
saintifik dalam kegiatan pembelajaran. 2) Guru, disarankan agar dapat menerapkan model picture and picture berbasis pendekatan saintifik sebagai salah satu alternatif pembelajaran dalam rangka meningkatkan penguasaan kompetensi pengetahuan siswa.

Peneliti lain, yang ingin dan tertarik untuk melaksanakan penelitian menggunakan model picture and picture maupun pendekatan saintifik disarankan agar dapat menggunakan hasil penelitian ini sebagai bahan kajian sebagai pertimbangan untuk meneliti masalah lain dengan cakupan yang lebih luas maupun aspek penguasaan kompetensi yang lain.

\section{Daftar Pustaka}

Agung, A. A. Gede. (2012). Metodologi Penelitian Pendidikan. Singaraja: Fakultas Ilmu Pendidikan UNDIKSHA.

Agung, A. A. Gede. (2014). Metodologi Penelitian Pendidikan. Malang: Aditya Media Publinshing.

Aly, Abdullah;Eny Rahma. (2009). Ilmu Alamiah Dasar. Jakarta: Bumi Akara.

Aprudin. (2012). Model-model Penelitian Tindakan Kelas Menurut Para Ahli [Online]. Tersedia: http://007indien.blogspot.com/2012/05/model-model-penelitian-tindakan-kelas.html .[17 April 2013]

Astiti, Desak Kadek Sri, I Wayan Widiana. (2017). Penerapan Metode Pembelajaran Jigsaw Sebagai Upaya Meningkatkan Hasil Belajar IPA Pada Siswa Kelas IV SD. Jurnal Ilmiah Sekolah Dasar. Vol.1 (1) pp. 30-41.

Daniel Winantara, IW., I Nyoman Laba Jayanta. (2017). Penerapan Model Pembelajaran TPS Untuk Meningkatkan Hasil Belajar IPA Siswa Kelas V SD No 1 Mengwitani. Jurnal Ilmiah Sekolah Dasar. Vol. 1 No. 1.

Daryanto. (2014). Pendekatan Pembelajaran Saintifik Kurikulum 2013. Yogyakarta: Gava Media.

Febrian Kurniasari, Elisabet., Eunice Widyanti Setyaningtyas. (2017). Peningkatan Hasil Belajar IPS Melalui Penerapan Model Pembelajaran Kooperatif Tipe Think Pair and Share (TPS) dengan Teknik Gallery Walk. Journal of Education Research and Evaluation. Vol. 1 No. 2.

Juniati, Ni Wayan., I Wayan Widiana. (2017). Penerapan Model Pembelajaran Inkuiri Untuk Meningkatkan Hasil Belajar IPA. Jurnal Ilmiah Sekolah Dasar. Vol. 1 No. 1.

Kosasih, E. (2015). Startegi Belajar dan Pembelajaran Implementasi Kurikulum 2013. Bandung: Yrama Widya.

Kurniasih, Imas. (2015). Ragam Pengembangan Model Pembelajaran. Kuningan: Kata Pena.

Hamdani. (2010). Strategi Belajar Mengajar. Bandung: Pustaka Setia

Purwanto. (2008). Metodologi Penelitian Kuantitatif untuk Psikologi dan Pendidikan. Yogyakarta: Pustaka Pelajar.

Peraturan Menteri Pendidikan dan Kebudayaan Republik Indosesia No. 57 Tahun 2014 Tentang Kurikulum 2013 Sekolah Dasar/Madrasah Ibtidaiyah, 2014. Jakarta: Kementerian Pendidikan dan Kebudayaan.

Peraturan Menteri Pendidikan dan Kebudayaan Republik Indosesia No. 103 Tahun 2014 Tentang Pembelajaran Pada Pendidikan Dasar Dan Pendidikan Menengah, 2014. Jakarta: Kementerian Pendidikan dan Kebudayaan.

Samatowa, Usman. (2010). Pembelajaran IPA di Sekolah Dasar. Jakarta: Indeks Permata Putri Media.

Suharsimi, Arikunto.( 2010). Penelitian Tindakan Kelas. Jakarta: Bumi Aksara.

Sawitra, Gita Bagus. (2015). Pengaruh Picture dan Picture berbantuan Power Point Terhadap Keterampilan Menulis Karangan Narasi Siswa Kelas IV SD di Gugus III Udayana, Kecamatan Mendoyo, Kabupaten Jembrana Tahun Pelajaran 2014/2015. Tersedia pada (http://ejournal.undiksha.ac.id/index.php/IJPGSD/article/view/5748) diakses pada tanggal 18 Pebruari 2016.

Suryadi, Ace. (2009). Mewujudkan Masyarakat Pembelajar. Bandung: Widya Aksara Pres. 
Utami Ulan Dewi, Gusti Ayu Ketut., I Wayan Widiana, I Ketut Dibia. (2016). Analisis Interaksi Guru dan Siswa Dalam Pembelajaran Bahasa Indonesia di Kelas 1 sdn 1 Nawa Kerti. Mimbar PGSD. Vol. 4 No. 1.

Tillar. (2000). Paradigma Baru Pendidikan Nasional. Jakarta: Rineka Cipta.

Trianto. (2007). Model Pembelajaran Terpadu dalam Teori dan Praktek. Jakarta: Prestasi Pustaka Publisher.

Trianto, (2008). Mendesain Pembelajaran Kontekstual (Contextual Teaching and Learning) di Kelas. Jakarta: Cerdas Pustaka Publisher.

Widiana, Wayan., dkk. (2015). Pengaruh Pendekatan Saintifik dan Kepercayaan Diri Terhadap hasil Belajar IPA. E-Journal PGSD Universitas Pendidikan Ganesha. Volume 3 No. 1 Tahun 2015. 